\section{Substrate Water Content Influences the Flowering of Doritaenopsis Queen Beer 'Mantefon'}

\author{
Yong Ha Rhie \\ Department of Horticulture and Forestry, Pai Chai University, Daejeon \\ 35345, Korea \\ Seonghwan Kang \\ Department of Biosystems and Biotechnology, Korea University, Seoul \\ 02841, Korea
}

\section{Jongyun Kim ${ }^{1}$ \\ Division of Biotechnology, Korea University, Seoul 02841, Korea}

Additional index words. automated irrigation, capacitance sensor, crassulacean acid metabolism, drought, Sphagnum moss

\begin{abstract}
Automated irrigation systems based on soil moisture sensor measurements can reduce water and fertilizer use while adequately meeting plant water requirements. In this study, the effects of substrate volumetric water content $(\theta, v / v)$ on the flowering of 17 month-old Doritaenopsis Queen Beer 'Mantefon' (from the time of deflasking) were examined. The plants were transplanted in plastic pots $(10.5 \mathrm{~cm}$ width $\times 9.5 \mathrm{~cm}$ height $)$ filled with sphagnum moss and the $\theta$ of sphagnum moss was maintained at $0.2,0.3,0.4$, or $0.5 \mathrm{~m}^{3} \cdot \mathrm{m}^{-3}$ using an automated drip irrigation system. Plants grown at a $\theta$ threshold of $0.2 \mathrm{~m}^{3} \cdot \mathrm{m}^{-3}$ had thinner leaves and lower SPAD value than those grown at higher $\theta$ thresholds. The net $\mathrm{CO}_{2}$ uptake of the uppermost fully expanded leaf increased with increasing $\theta$ between 0.2 and $0.4 \mathrm{~m}^{3} \cdot \mathrm{m}^{-3}$, but there was no significant difference in the net $\mathrm{CO}_{2}$ uptake between plants grown at 0.4 and $0.5 \mathrm{~m}^{3} \cdot \mathrm{m}^{-3}$ thresholds. The number of flower buds at the time of the first open flower was lower in plants grown at $\theta$ thresholds of 0.2 and $0.3 \mathrm{~m}^{3} \cdot \mathrm{m}^{-3}$ as compared with that in the plants grown at 0.4 and $0.5 \mathrm{~m}^{3} \cdot \mathrm{m}^{-3}$ thresholds. Early flower abscission, flower bud dropping, and flower senescence during the 2 weeks after flowering occurred in $55 \%$ and $30 \%$ of the plants at 0.2 and $0.3 \mathrm{~m}^{3} \cdot \mathrm{m}^{-3}$ thresholds, respectively, whereas plants at $\theta$ thresholds of 0.4 and $0.5 \mathrm{~m}^{3} \cdot \mathrm{m}^{-3}$ had negligible flower abscission. Although vegetative growth parameters were similar among $\theta$ thresholds of $0.3 \mathrm{~m}^{3} \cdot \mathrm{m}^{-3}$ or higher, plants grown at a $\theta$ threshold of $0.3 \mathrm{~m}^{3} \cdot \mathrm{m}^{-3}$ produced fewer flowers than those grown at 0.4 and $0.5 \mathrm{~m}^{3} \cdot \mathrm{m}^{-3}$ thresholds. During the 83-day experimental period, the system irrigated the plants $\approx 0.79,1.93,2.46$, and $2.84 \mathrm{~L} /$ pot at $\theta$ thresholds of $0.2,0.3,0.4$, and $0.5 \mathrm{~m}^{3} \cdot \mathrm{m}^{-3}$, respectively. Overall, $0.4 \mathrm{~m}^{3} \cdot \mathrm{m}^{-3}$ was considered to be an optimal threshold $\theta$ level for producing high-quality Doritaenopsis Queen Beer 'Mantefon' during the flowering period with most efficient water use.
\end{abstract}

Phalaenopsis has become the most important ornamental crop with high economic value in international flower markets (Gow et al., 2010). Phalaenopsis has been the bestselling pot plant in the Dutch flower-auctions since 2000 , and 135 million pots were sold in 2016 (Vereniging van Bloemenveilingen in Nederland, 2017). In the United States, orchids are the most valuable flowering crop; 36.4 million pots worth $\$ 288$ million were sold in 2015 (USDA, 2016). Among all the orchid genera sold in the United States,

\footnotetext{
Received for publication 12 May 2017. Accepted for publication 7 Nov. 2017.

This research was supported by Korea University Grant and the Korea Institute of Energy Technology Evaluation and Planning (KETEP), the Ministry of Trade, Industry and Energy of the Republic of Korea (No. 20142020103570).

${ }^{1}$ Corresponding author. E-mail: jongkim@korea. ac.kr.
}

size (Hwang and Jeong, 2007; Wang and Lee, 1994).

Human population growth, climate change, and increased agricultural and industrial water demands are likely to lead to a decrease in the availability of fresh water worldwide (IPCC, 2007). In the United States, laws and regulations currently limit the amount of water available for use in nurseries in across California, Florida, North Carolina, Texas, and Oregon, or in parts thereof. Moreover, such regulations are expected to become stricter (Fulcher et al., 2016). Nevertheless, water is commonly applied excessively in greenhouse production to assure complete wetness of the growing medium. Conventional irrigation with timers may result in unnecessary water application and runoff because a set irrigation volume is provided regardless of substrate moisture condition or plant water status (Alem et al., 2015). Models estimating daily water requirements from plant size and environmental factors such as daily light integral (DLI) and vapor pressure deficit (VPD) have been developed. However, they are not easy to adapt for ornamental plant production owing to varying environmental conditions across production areas (Kim et al., 2011). Capacitance soil moisture sensors have been successfully used to monitor moisture content in horticultural substrates and control irrigation to maintain a constant substrate moisture level with little or no leaching (Burnett and van Iersel, 2008; Nemali and van Iersel, 2006). By controlling irrigation using soil moisture sensors, experienced growers could save $22 \%$ to $83 \%$ of the water currently used in a commercial nursery setting (Pershey et al., 2015; van Iersel et al., 2009; Warsaw et al., 2009). Furthermore, soil moisture sensor systems allowing for real-time monitoring and thresholds for triggering irrigation can easily be adjusted to meet changing water demand or environmental conditions. The use of automated irrigation with soil moisture sensors to monitor and control substrate/soil water content has been examined for several species, ranging from woody species, such as Rhododendron spp. (Lea-Cox et al., 2008) and Hydrangea (van Iersel et al., 2009), to herbaceous species, such as Petunia (Kim et al., 2011).

In the United States and Europe, bark is preferentially used as a substrate because it provides good aeration for roots. However, bark has a poor water-holding ability, which necessitates irrigation that is more frequent and results in water and fertilizer wastage (Wang and Gregg, 1994). Sphagnum moss holds water more effectively than bark and has been used as a substrate for epiphyte orchid cultivation mainly in Eastern Asia, including China, Japan, Korea, and Taiwan (Kim et al., 2016; Yen et al., 2011). The objective of the present study was to compare the flowering of Doritaenopsis Queen Beer 'Mantefon', potted with sphagnum moss and maintained at various substrate moisture levels, using soil moisture sensor-based automated irrigation. 


\section{Materials and Methods}

Plant material and growth conditions. Mature Doritaenopsis Queen Beer 'Mantefon' plantlets, growing for $\approx 17$ months under ex vitro conditions planted on sphagnum moss in plastic pots $(9.0 \mathrm{~cm}$ diameter, 8.5 $\mathrm{cm}$ height), were purchased from a commercial propagator (Goyang Farming Association Co., Gyeonggi, Korea) on 4 Mar. 2016. On arrival at the laboratory, these plants were transplanted in $475-\mathrm{mL}$ transparent plastic pots ( $10.5 \mathrm{~cm}$ diameter, $9.5 \mathrm{~cm}$ height), filled with Chilean sphagnum moss (Sphagnum magellanicum; Lonquen Ltd., Pueto Montt, Chile) in the empty space of pots, and placed in a glasshouse located at Korea University, Seoul, South Korea, for $28 \mathrm{~d}$ before the experiment began. When filled with sphagnum moss, we used the same sphagnum moss as that used for the young plants, packed to a final bulk density of $\approx 0.3 \mathrm{~g} \cdot \mathrm{cm}^{-3}$. Transplanted plants were watered manually for 4 weeks to acclimate them to the experimental glasshouse environment. We fully watered all the plants on 25 Mar. and did not irrigate until the automated irrigation began on $1 \mathrm{Apr}$. When treatments began on 1 Apr. 2016, the number of leaves, leaf span, and length and width of the uppermost fully expanded leaf were $8.0 \pm 1.2$ (mean $\pm \mathrm{SD}, n=4), 30.4 \pm 2.3$ $\mathrm{cm}, 18.4 \pm 2.2 \mathrm{~cm}$, and $7.2 \pm 0.6 \mathrm{~cm}$, respectively. Inflorescences had already initiated on all of these plants and were 9.2 \pm 3.4 $\mathrm{cm}$ in length on 1 Apr. The experiment was carried out from 1 Apr. to 23 June 2016. The temperature, VPD, and DLI inside the glasshouse were measured using a temperature and humidity sensor (VP-3; Decagon Devices, Pullman, WA) and a photosynthetic photon flux sensor (QSO-Sun; Apogee Instruments, Logan, UT) connected to a data logger (CR1000; Campbell Scientific, Logan, UT). During the experiment, average day temperature, average night temperature, VPD, and DLI in the glasshouse were $24.9 \pm 4.4{ }^{\circ} \mathrm{C}($ mean $\pm \mathrm{SD}), 20.7 \pm 3.0^{\circ} \mathrm{C}$, $1.5 \pm 0.4 \mathrm{kPa}$, and $9.5 \pm 4.6 \mathrm{~mol} \cdot \mathrm{m}^{-2} \cdot \mathrm{d}^{-1}$, respectively.

Substrate hydraulic properties. The hydraulic properties of the Chilean sphagnum moss used in this experiment were determined using a modular instrument (Hyprop; UMS, München, Germany), following the method described by O'Meara et al. (2014).

Automated irrigation system. The experiment comprised four levels of substrate volumetric water content $(\theta, \mathrm{v} / \mathrm{v}): 0.2,0.3$, 0.4 , and $0.5 \mathrm{~m}^{3} \cdot \mathrm{m}^{-3}$. The $16 \mathrm{EC}-5$ capacitance soil moisture sensors (EC-5; Decagon Devices) were connected to a multiplexer (AM 16/32B; Campbell Scientific) which was connected to a data logger (CR1000; Campbell Scientific). The soil moisture sensors were powered by the data logger with $2.5 \mathrm{~V}$ excitation and calibrated to the specific substrate (sphagnum moss) used in this study $\left(\theta=0.001415 x-0.44315, r^{2}=0.9594\right)$. Each sensor $(5.5 \mathrm{~cm}$ length and $1.0 \mathrm{~cm}$ width) was inserted diagonally from the top of the substrate in the center of a pot, where the roots were located, to a depth of $\approx 6.0 \mathrm{~cm}$. The data logger was connected to one relay driver (SDM-CD16AC; Campbell Scientific) which controlled the power to 16 solenoid valves (S-390-2-R; Bermad, Kibbutz, Israel). Each experimental unit had five plants as subreplicates. The $\theta$ was measured every $10 \mathrm{~s}$ for one pot in the center for each experimental unit. Every $20 \mathrm{~min}$, if the $\theta$ reading of the capacitance sensors in an experimental unit dropped below the assigned $\theta$ set point, the data logger opened the solenoid valve for that experimental unit for $30 \mathrm{~s}$. Plants were irrigated using a customized drip ring with a pressure-compensated drip emitter (Netafim $2 \mathrm{~L} \cdot \mathrm{h}^{-1}$; Netafim, Fresno, CA) placed around the plant at a rate of $16.7 \mathrm{~mL}$ per plant per irrigation. Each irrigation application was recorded by the data logger, and the daily and total water applied to the plants was calculated based on the last $83 \mathrm{~d}$ of the experiment. During the experiment, plants were fertigated with a $20 \mathrm{~N}-8.7 \mathrm{P}-16.6 \mathrm{~K}$ water-soluble fertilizer

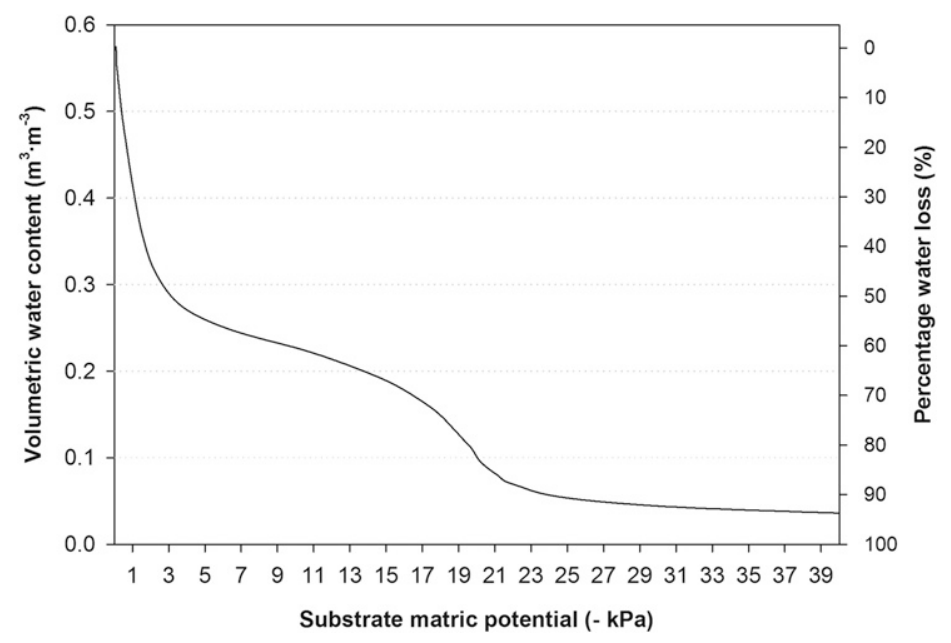

Fig. 1. Moisture retention curve of sphagnum moss.

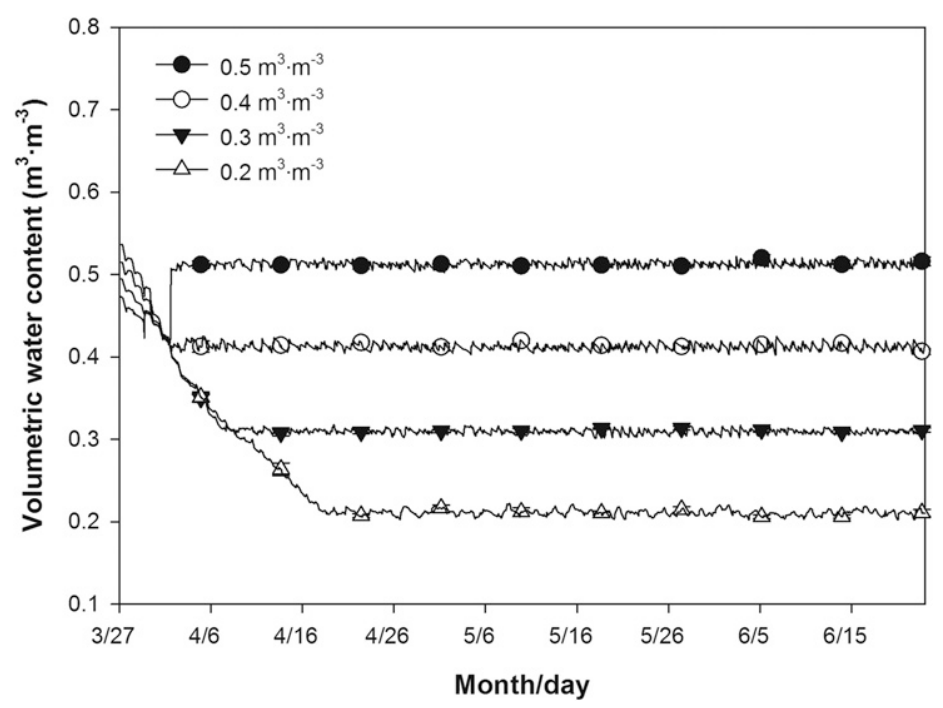

Fig. 2. Substrate volumetric water content $(\theta, \mathrm{v} / \mathrm{v})$ changes in Doritaenopsis Queen Beer 'Mantefon' with a soil moisture sensor-based automated irrigation system. Sphagnum moss was used as the substrate, and EC-5 soil moisture sensors were calibrated for the substrate. Error bars indicate SE $(n=4)$. 
The flower bud dropping was based on the dropping of buds from the plant before flowering and flower senescence meant that a flower dropped within 2 weeks after opening. At the end of the experiment (on 23 June), the total number of leaves, leaf span, leaf thickness, length and width of the uppermost fully expanded leaf, total leaf area, SPAD value, inflorescence length, flower length, flower width, and fresh and dry weight of shoots and roots were determined. Flower size and inflorescence length were determined based on the largest one in each pot. SPAD value was measured using a chlorophyll meter (SPAD 502; Minolta, Osaka, Japan). Total leaf area was measured using a leaf area meter (LI-3100; LI-COR, Lincoln, NE). Dry weights were determined after drying samples in an oven at $80{ }^{\circ} \mathrm{C}$ for $4 \mathrm{~d}$.

Gas exchange. Phalaenopsis absorbs $\mathrm{CO}_{2}$ mainly during the night, demonstrating typical crassulacean acid metabolism (CAM) photosynthetic characteristics (Guo and Lee, 2006). To determine the best time for measuring the photosynthetic parameters of Doritaenopsis Queen Beer 'Mantefon', we measured diurnal variations in gas exchange using a portable photosynthesis system, CIRAS-3 (PP Systems, Amesbury, MA), with a PLC 3 universal leaf cuvette on 16 June 2016, which was a clear day. In the preliminary experiment, it was determined that the time from 0200 to $0400 \mathrm{HR}$ to be the optimal period to measure $\mathrm{CO}_{2}$ uptake in Phalaenopsis. The cuvette was placed in the middle of the leaf next to the vein on an uppermost fully expanded leaf. The rate of airflow through the cuvette was $\approx 200$ $\mathrm{mL} \cdot \mathrm{min}^{-1}$ with a $\mathrm{CO}_{2}$ level of 400 $\mu \mathrm{mol} \cdot \mathrm{mol}^{-1}$. After a steady state of gas exchange had been achieved, the net $\mathrm{CO}_{2}$ uptake rate, stomatal conductance $\left(g_{\mathrm{s}}\right)$, and transpiration rate were determined for $10-20 \mathrm{~s}$ until the values stabilized. For these measurements, the uppermost mature leaves on eight randomly selected plants per treatment were used. These leaves existed at the beginning of the treatment.

Stomatal frequency on leaf epidermis. The middle portion of an emerging new leaf was chosen to measure the stomatal frequency (number of stomata/total number of epidermal cells) in $1 \mathrm{~mm}^{2}$ area, and leaves on four randomly selected plants per treatment were sampled. An abaxial leaf epidermis replica was prepared using clear commercial nail polish and the number of stomata was counted under a microscope (YS100; Nikon, Ibaraki, Japan) at $\times 100$ magnification

Experimental design and analysis. The experiment used a randomized complete block design with four treatments and four blocks. Each experimental unit had five plants and $\theta$ was measured for one pot in the center of each unit. The effects of various $\theta$ thresholds on the inflorescence length, the number of flower buds at the time of the first open flower, and other growth parameters at harvest were analyzed using analysis of variance, followed by Tukey's honestly significant difference $(P=0.05)$ procedure using SAS 9.4 (SAS Institute, Cary, NC).

\section{Results and Discussion}

Substrate hydraulics. The total porosity of the sphagnum moss was $0.57 \mathrm{~m}^{3} \cdot \mathrm{m}^{-3}$ and the substrate matric potential decreased to

Table 1. Effects of volumetric water content of substrate on the vegetative characteristics of Doritaenopsis Queen Beer 'Mantefon' at $83 \mathrm{~d}$ after the start of treatment.

\begin{tabular}{lccccccc}
\hline $\begin{array}{l}\text { Volumetric water } \\
\text { content } \\
\left(\theta, \mathrm{m}^{3} \cdot \mathrm{m}^{-3}\right)\end{array}$ & $\begin{array}{c}\text { No. } \\
\text { leaves }\end{array}$ & $\begin{array}{c}\text { Leaf } \\
\text { span } \\
(\mathrm{cm})\end{array}$ & $\begin{array}{c}\text { Leaf } \\
\text { thickness } \\
(\mathrm{mm})\end{array}$ & $\begin{array}{c}\text { Leaf } \\
\text { length } \\
(\mathrm{cm})\end{array}$ & $\begin{array}{c}\text { Leaf } \\
\text { width } \\
(\mathrm{cm})\end{array}$ & $\begin{array}{r}\text { Total leaf } \\
\text { area }\left(\mathrm{cm}^{2}\right)\end{array}$ & $\begin{array}{l}\text { SPAD } \\
\text { value }\end{array}$ \\
\hline 0.2 & 6.20 & 37.4 & $1.56 \mathrm{~b}^{\mathrm{z}}$ & 19.6 & 7.04 & 417.4 & $59.7 \mathrm{~b}$ \\
0.3 & 6.55 & 38.0 & $1.98 \mathrm{a}$ & 19.2 & 6.83 & 457.0 & $65.1 \mathrm{a}$ \\
0.4 & 6.90 & 37.4 & $2.15 \mathrm{a}$ & 18.8 & 7.03 & 449.0 & $66.8 \mathrm{a}$ \\
0.5 & 6.85 & 37.3 & $2.16 \mathrm{a}$ & 18.8 & 6.94 & 444.8 & $66.0 \mathrm{a}$ \\
& & & & & & & NS \\
Significance & $\mathrm{NS}$ & $\mathrm{NS}$ & $* *$ & NS & $* * *$ \\
\hline
\end{tabular}

${ }^{\mathrm{z}}$ Mean separation within columns by Tukey's honestly significant difference test at $P=0.05$.

NS, *** Nonsignificant or significant at $P \leq 0.001$, respectively.

Table 2. Effects of volumetric water content thresholds at which fertigation was applied in a greenhouse on days to first open flower, inflorescence length, and number of flower buds at first open flower of Doritaenopsis Queen Beer 'Mantefon'.

\begin{tabular}{lccc}
\hline $\begin{array}{l}\text { Volumetric water } \\
\begin{array}{l}\text { content } \\
\left(\theta, \mathrm{m}^{3} \cdot \mathrm{m}^{-3}\right)\end{array}\end{array}$ & $\begin{array}{c}\text { Days to first } \\
\text { open flower }\end{array}$ & $\begin{array}{c}\text { Inflorescence } \\
\text { length }(\mathrm{cm})\end{array}$ & $\begin{array}{c}\text { No. flower buds at } \\
\text { first open flower }\end{array}$ \\
\hline 0.2 & $50.2 \mathrm{a}^{\mathrm{z}}$ & $36.1 \mathrm{~b}$ & $13.4 \mathrm{~b}$ \\
0.3 & $48.8 \mathrm{ab}$ & $35.8 \mathrm{~b}$ & $12.7 \mathrm{~b}$ \\
0.4 & $45.6 \mathrm{c}$ & $40.1 \mathrm{a}$ & $16.3 \mathrm{a}$ \\
0.5 & $47.4 \mathrm{bc}$ & $39.4 \mathrm{ab}$ & $15.4 \mathrm{a}$ \\
Significance & $* * *$ & $* *$ & $* * *$ \\
\hline
\end{tabular}

${ }^{\mathrm{z}}$ Mean separation within columns by Tukey's honestly significant difference test at $P=0.05$.

**, ***Significant at $P \leq 0.01$ or 0.001 , respectively.

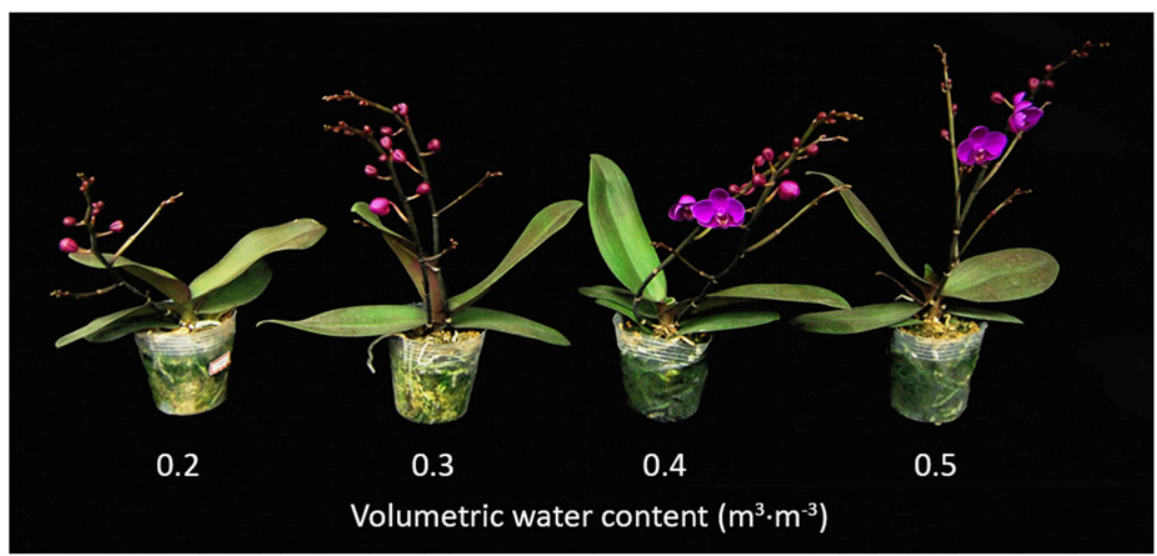

Fig. 3. Effect of volumetric water content of the substrate on Doritaenopsis Queen Beer 'Mantefon' grown for $54 \mathrm{~d}$.

Table 3. Effects of volumetric water content of substrate on the flowering and fresh and dry weight of Doritaenopsis Queen Beer 'Mantefon' $83 \mathrm{~d}$ after the start of treatment.

\begin{tabular}{|c|c|c|c|c|c|c|c|}
\hline \multirow{2}{*}{$\begin{array}{l}\text { Volumetric water } \\
\text { content }\left(\theta, \mathrm{m}^{3} \cdot \mathrm{m}^{-3}\right)\end{array}$} & \multirow[b]{2}{*}{ No. flowers } & \multirow{2}{*}{$\begin{array}{c}\text { Flower } \\
\text { length }(\mathrm{cm})\end{array}$} & \multirow{2}{*}{$\begin{array}{c}\text { Flower } \\
\text { width }(\mathrm{cm})\end{array}$} & \multicolumn{2}{|c|}{ Fresh wt (g) } & \multicolumn{2}{|c|}{ Dry wt (g) } \\
\hline & & & & Shoot & $\overline{\text { Root }}$ & Shoot & Root \\
\hline$\overline{0.2}$ & $19.0 b^{z}$ & $3.5 \mathrm{~b}$ & $4.8 \mathrm{~b}$ & $92.0 \mathrm{~b}$ & $38.7 \mathrm{~b}$ & $8.9 \mathrm{~b}$ & $4.8 \mathrm{~b}$ \\
\hline 0.3 & $24.5 \mathrm{ab}$ & $3.8 \mathrm{a}$ & $5.3 \mathrm{a}$ & $125.8 \mathrm{a}$ & $54.8 \mathrm{a}$ & $10.4 \mathrm{a}$ & $5.3 \mathrm{a}$ \\
\hline 0.4 & $28.1 \mathrm{a}$ & $4.0 \mathrm{a}$ & $5.3 \mathrm{a}$ & $129.0 \mathrm{a}$ & $56.3 \mathrm{a}$ & $10.5 \mathrm{a}$ & $5.1 \mathrm{a}$ \\
\hline 0.5 & $25.6 \mathrm{a}$ & $3.8 \mathrm{a}$ & $5.3 \mathrm{a}$ & $127.7 \mathrm{a}$ & $59.2 \mathrm{a}$ & $10.2 \mathrm{a}$ & $5.1 \mathrm{a}$ \\
\hline Significance & $* *$ & $* * *$ & $* * *$ & $* * *$ & $* * *$ & $* * *$ & $* * *$ \\
\hline
\end{tabular}

${ }^{\mathrm{z}}$ Mean separation within columns by Tukey's honestly significant difference test at $P=0.05$.

**, ***Significant at $P \leq 0.01$ or 0.001 , respectively. 
$-40 \mathrm{kPa}$ at a substrate $\theta$ of $\approx 0.04 \mathrm{~m}^{3} \cdot \mathrm{m}^{-3}$ (Fig. 1). When the substrate $\theta$ was $0.5,0.4$, 0.3 , and $0.2 \mathrm{~m}^{3} \cdot \mathrm{m}^{-3}$, the substrate matric potential was $-0.4,-1.1,-2.6$, and $-13.6 \mathrm{kPa}$, respectively. Previously, Wang (2010) reported the substrate hydraulic properties in sphagnum moss for growing Phalaenopsis. In that study, moisture tension was maintained at $0 \mathrm{kPa}$ until $33 \%$ of the total water being held by the sphagnum moss was lost. In our results, when a substrate $\theta$ was $0.4 \mathrm{~m}^{3} \cdot \mathrm{m}^{-3}, \approx 30 \%$ of the total water was lost and the substrate matric potential dropped to $-1.1 \mathrm{kPa}$ (Fig. 1), which agrees with that reported by Wang (2010).

Automated irrigation system. The $\theta$ measurements in the moss decreased gradually until automated irrigation began on 1 Apr. (Fig. 2). Automated irrigation occurred when the substrate dried below the designated $\theta$ threshold and automation worked properly with very little variation $\left( \pm 0.004 \mathrm{~m}^{3} \cdot \mathrm{m}^{-3}\right.$ of $\left.\mathrm{SD}\right)$ throughout the experiment. Irrigation started immediately on 1 Apr. in the 0.4 and $0.5 \mathrm{~m}^{3} \cdot \mathrm{m}^{-3}$ $\theta$ threshold treatments, whereas it took 6 and 16 more days to start irrigation for the 0.3 and $0.2 \mathrm{~m}^{3} \cdot \mathrm{m}^{-3} \theta$ threshold treatments, respectively. Thereafter, the $\theta$ in each pot was maintained just above the allocated threshold consistently throughout the experiment. For petunia cultivation in a greenhouse, an automated irrigation system with capacitance soil moisture sensors could maintain the soil moisture status within a narrow range during cultivation (Kim et al., 2011).

Vegetative growth and flowering. Because all the plants had entered their reproductive stage with young inflorescences at the beginning of the treatment, and no new leaf was produced during the 89-d experimental period, the treatments had no effect on leaf growth. No significant differences were found in leaf span, length and width of the uppermost fully expanded leaf, and the total leaf area among the plants grown at the various $\theta$ thresholds (Table 1 ). The leaves of plants grown at a $\theta$ threshold of $0.2 \mathrm{~m}^{3} \cdot \mathrm{m}^{-3}$ were $27 \%, 37 \%$, and $38 \%$ thinner than those grown at $\theta$ thresholds of $0.3,0.4$, and 0.5 $\mathrm{m}^{3} \cdot \mathrm{m}^{-3}$, respectively. SPAD value (greener leaves at higher values) was lower in plants grown at a $\theta$ threshold of $0.2 \mathrm{~m}^{3} \cdot \mathrm{m}^{-3}(59.7)$ than in those grown at higher $\theta$ thresholds of $0.3,0.4$, and $0.5 \mathrm{~m}^{3} \cdot \mathrm{m}^{-3}(65.1,66.8$, and 66.0, respectively). Similar effects have been reported in avocado and olive, where leaves were thinner and leaf total chlorophyll content was lower in water-stressed lower than in well-watered plants (Chartzoulakis et al., 2002; Guerfel et al., 2009). In general, although vegetative growth has been found to decrease with decreasing $\theta$ thresholds (Bayer et al., 2013; Kim et al., 2012; Nemali and van Iersel, 2006), there was no difference in vegetative growth due to $\theta$ thresholds in our study.

As the $\theta$ threshold decreased, the number of days to first open flower increased and inflorescence length and the number of flower buds at first open flower decreased (Table 2; Fig. 3), although there was no difference between the plants at 0.4 and $0.5 \mathrm{~m}^{3} \cdot \mathrm{m}^{-3}$ thresholds. At harvest, plants grown at a $\theta$ threshold of $0.2 \mathrm{~m}^{3} \cdot \mathrm{m}^{-3}$ had the fewest flowers and smaller flowers than those on the plants grown at higher $\theta$ thresholds (Table 3). Moreover, previous work has shown that plants grown at lower $\theta$ thresholds had fewer flowers than those at higher $\theta$ thresholds in petunia and impatiens (Blanusa et al., 2009), cut rose (Chimonidou-Pavlidou, 2004), and Big Bend bluebonnet (Niu et al., 2007). Fresh weight and dry weight accumulation showed a similar pattern, with lower fresh and dry weights at a $\theta$ threshold of $0.2 \mathrm{~m}^{3} \cdot \mathrm{m}^{-3}$ than at higher $\theta$ thresholds (Table 3). There was no difference in these values among the plants grown at $\theta$ thresholds of $0.3 \mathrm{~m}^{3} \cdot \mathrm{m}^{-3}$ and greater.

Under $\theta$ thresholds of 0.2 and $0.3 \mathrm{~m}^{3} \cdot \mathrm{m}^{-3}$, early flower abscission occurred in $55 \%$ and $30 \%$ of the plants, respectively, occurring at $\approx 13 \mathrm{~d}$ from the first open flower (Fig. 4).
Plants at the $0.4 \mathrm{~m}^{3} \cdot \mathrm{m}^{-3}$ threshold showed reduced flower abscission, and no flower abscission was observed at a $\theta$ threshold of $0.5 \mathrm{~m}^{3} \cdot \mathrm{m}^{-3}$. Fertigation at various $\theta$ thresholds might affect nutrient availability to plants and water availability. In previous studies, lower fertilizer concentrations produced smaller leaves in Phalaenopsis (Wang, 2010; Wang and Gregg, 1994) and showed symptoms of nutrient deficiency, such as yellowish leaves that eventually abscised (Wang, 2007). However, in our study there was no symptom of nutrient deficiency, such as yellowish leaves in any treatments. Early flower abscission under lower $\theta$ thresholds in our results was likely because of water stress and reduced turgor rather than because of lack of nutrition. Early nutrient termination did not severely affect flowering longevity in Phalaenopsis compared with continuous application of fertilizer (Wang, 2000).

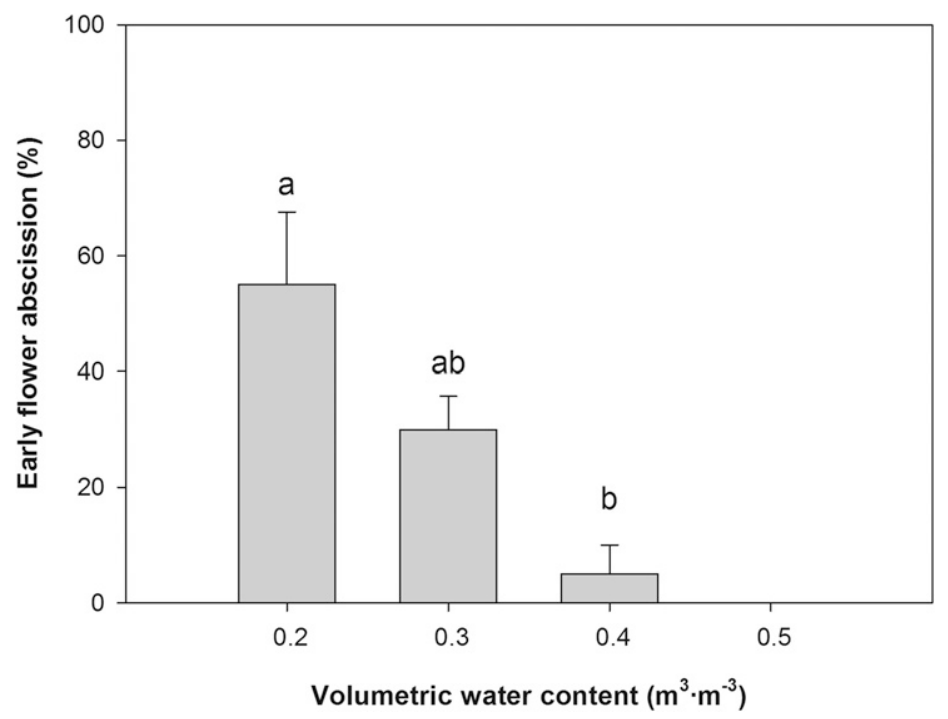

Fig. 4. Percentage of early flower abscission in Doritaenopsis Queen Beer 'Mantefon' after $83 \mathrm{~d}$ at four volumetric water content thresholds. Mean separation by Tukey's honestly significant difference test at $P \leq 0.05$. Error bars indicate SE $(n=4)$.

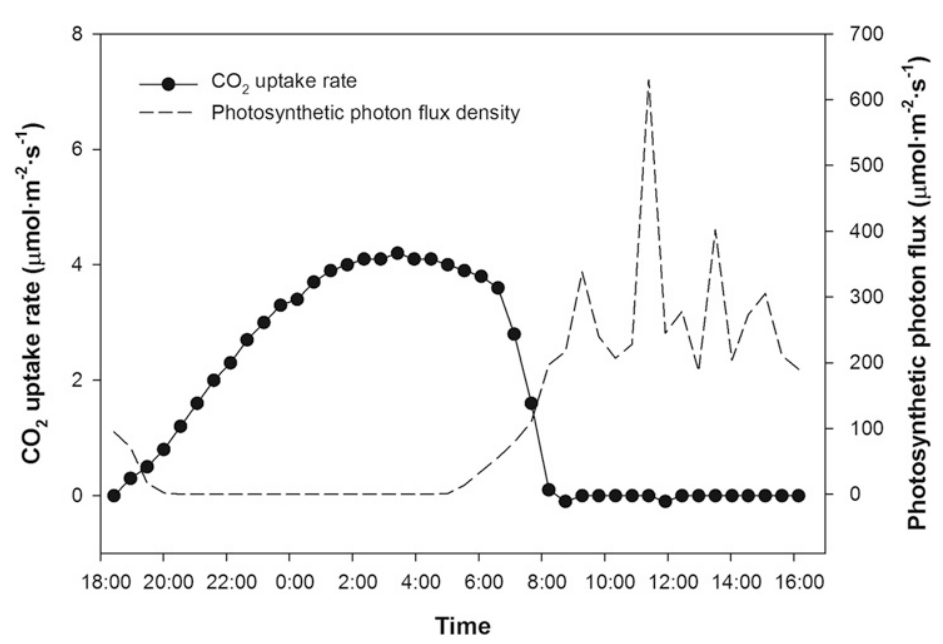

Fig. 5. The net $\mathrm{CO}_{2}$ uptake rate of the leaf of Doritaenopsis Queen Beer 'Mantefon' during a 24-h period. Measurements were conducted on 16 June 2016. 
Gas exchange and stomata. The time from 0200 to $0400 \mathrm{HR}$ was found to be the optimal time to measure the gas exchange of Doritaenopsis Queen Beer 'Mantefon'

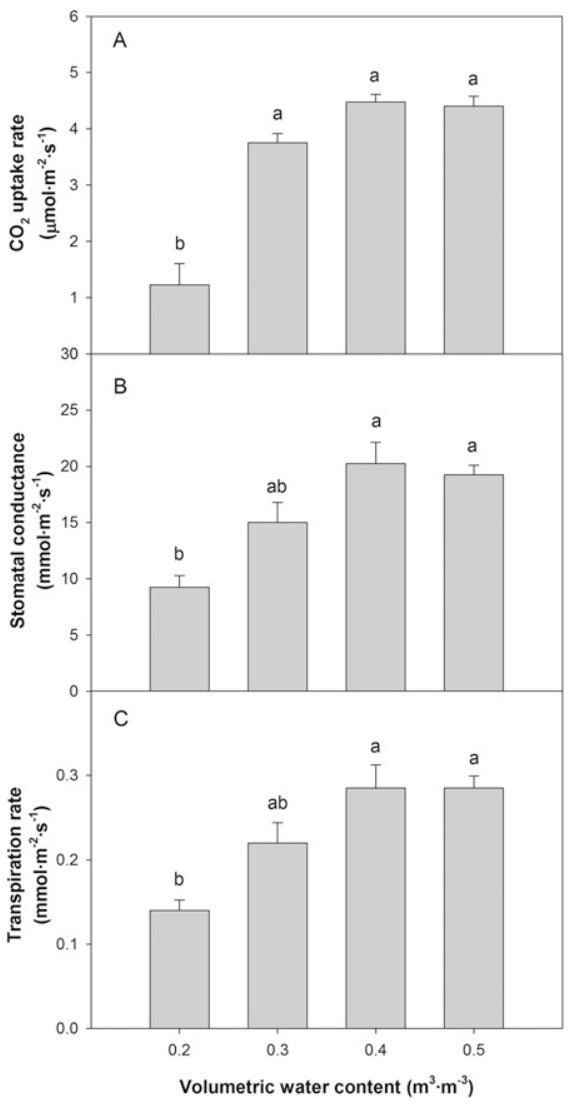

Fig. 6. Net $\mathrm{CO}_{2}$ uptake rate (A), stomatal conductance $(\mathbf{B})$, and transpiration rate $(\mathbf{C})$ in the uppermost fully expanded leaves of Doritaenopsis Queen Beer 'Mantefon' after $80 \mathrm{~d}$ under four volumetric water content thresholds. Mean separation by Tukey's honestly significant difference test at $P \leq 0.05$. Error bars indicate SE $(n=4)$.
(Fig. 5). This pattern was similar to that observed in other Phalaenopsis spp. (Guo and Lee, 2006). Net $\mathrm{CO}_{2}$ uptake rates from 0200 to $0400 \mathrm{HR}$ at $\theta$ thresholds of $0.2,0.3$, 0.4 , and $0.5 \mathrm{~m}^{3} \cdot \mathrm{m}^{-3}$ were $1.23,3.75,4.48$, and $4.40 \mu \mathrm{mol} \cdot \mathrm{m}^{-2} \cdot \mathrm{s}^{-1}$, respectively (Fig. 6). The photosynthetic rate increased with increasing $\theta$ threshold from 0.2 to $0.3 \mathrm{~m}^{3} \cdot \mathrm{m}^{-3}$, with no additional increase as $\theta$ increased further. Similarly, $g_{\mathrm{s}}$ and transpiration rate increased with $\theta$ threshold between 0.2 and $0.4 \mathrm{~m}^{3} \cdot \mathrm{m}^{-3}$. Ota et al. (1991) reported that imposing water stress in Phalaenopsis by withholding water for $10 \mathrm{~d}$ induced lower $\mathrm{CO}_{2}$ uptake from the leaves. It has been established that the relative water content of leaves controls the stomatal movement of CAM plants at night (Nobel, 1977), and that the stomata of CAM plants tend to close under water stress, thus reducing $\mathrm{CO}_{2}$ uptake (Kluge and Ting, 2012). In addition, our results indicated that Phalaenopsis, an epiphyte, suffers from drought stress at a $\theta$ level below $0.2 \mathrm{~m}^{3} \cdot \mathrm{m}^{-3}$, which is about $-15 \mathrm{kPa}$ in a sphagnum moss substrate with the degree of compaction used in this study.

Stomatal density responds to environmental factors, such as drought and elevated $\mathrm{CO}_{2}$ concentration ( $\mathrm{Xu}$ and $\mathrm{Zhou}, 2008)$. In general, plants subjected to severe drought stress have low stomatal density as compared with plants grown in well-irrigated soils (Meng et al., 1999; Xu and Zhou, 2008). However, no significant differences were observed in stomatal density among the plants at four various $\theta$ thresholds in our experiment (data not shown). The reason for the absence of any difference in stomatal density among the treatments was likely because of the short experimental period for displaying any treatment effect on Phalaenopsis. However, our results showed that $g_{\mathrm{s}}$ decreased with decreasing $\theta$ threshold between $\theta$ values of 0.4 and $0.2 \mathrm{~m}^{3} \cdot \mathrm{m}^{-3}$ (Fig. 6). This is likely because

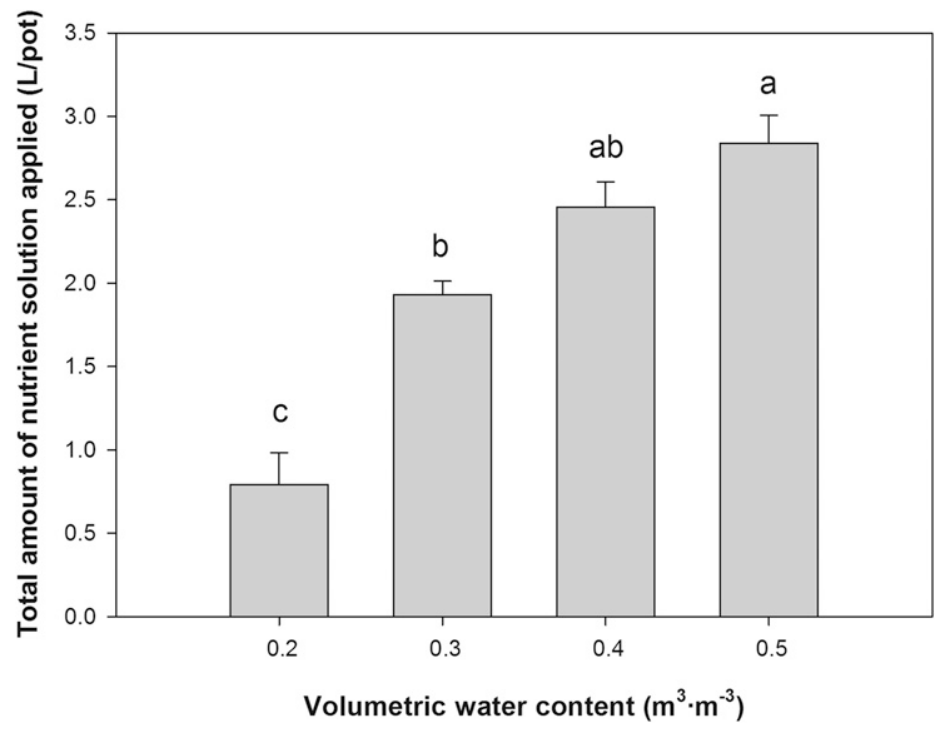

Fig. 7. The total amount of nutrient solution applied to growing Doritaenopsis Queen Beer 'Mantefon' for $83 \mathrm{~d}$ as affected by volumetric water content thresholds at which fertigation was performed in the greenhouse. Mean separation by Tukey's honestly significant difference test at $P \leq 0.05$. Error bars indicate $\operatorname{SE}(n=4)$.

of the direct closure of stomata. Drought stress is first sensed by the plant roots and activates the synthesis of the phytohormone ABA. The root-derived ABA is transported to leaves (Sauter et al., 2001) to induce stomatal closure and prevent stomatal opening through different pathways (Mishra et al., 2006).

Water use. The total fertigation volume decreased with the decrease in the $\theta$ threshold level (Fig. 7). In general, as compared with sprinkler systems and hand watering, drip irrigation reduces water and fertilizer losses due to leaching from substrates. In our experiment, no leaching was observed even at the highest $\theta$ threshold $\left(0.5 \mathrm{~m}^{3} \cdot \mathrm{m}^{-3}\right)$. Moreover, the total volume of water applied at a $\theta$ threshold of $0.2 \mathrm{~m}^{3} \cdot \mathrm{m}^{-3}$ was only $28 \%$ of that used by the plants grown at a $\theta$ threshold of $0.5 \mathrm{~m}^{3} \cdot \mathrm{m}^{-3}$ (Fig. 7). Although treatment at a $\theta$ threshold of $0.2 \mathrm{~m}^{3} \cdot \mathrm{m}^{-3}$ saved a considerable amount of water and nutrients, it produced poor quality Phalaenopsis with early flower abscission. Previous research has shown that sensor-controlled drip irrigation could be used to reduce irrigation volume without negative impacts on plant growth of bluebonnet (Niu et al., 2007), conifers (Pershey et al., 2015), geranium (Valdés et al., 2015), hibiscus (Bayer et al., 2013), and woody ornamentals (Warsaw et al., 2009) to a certain extent. Our results indicate that maintaining the sphagnum moss substrate at a $\theta$ of 0.4 or $0.5 \mathrm{~m}^{3} \cdot \mathrm{m}^{-3}$ produced quality Doritaenopsis Queen Beer 'Mantefon' with comparatively little water and nutrients $(2.84 \mathrm{~L} /$ pot for a $\theta$ threshold of $0.5 \mathrm{~m}^{3} \cdot \mathrm{m}^{-3}$ for $83 \mathrm{~d}$ ), without any leaching.

\section{Literature Cited}

Alem, P., P.A. Thomas, and M.W. van Iersel. 2015. Substrate water content and fertilizer rate affect growth and flowering of potted petunia. HortScience 50:582-589.

Bayer, A., I. Mahbub, M. Chappell, J. Ruter, and M.W. van Iersel. 2013. Water use and growth of Hibiscus acetosella 'Panama Red' grown with a soil moisture sensor-controlled irrigation system. HortScience 48:980-987.

Blanusa, T., E. Vysini, and R.W.F. Cameron. 2009. Growth and flowering of Petunia and Impatiens: Effects of competition and reduced water content within a container. HortScience 44:1302-1307.

Burnett, S.E. and M.W. van Iersel. 2008. Morphology and irrigation efficiency of Gaura lindheimeri grown with capacitance sensor-controlled irrigation. HortScience 43:1555-1560.

Chartzoulakis, K., A. Patakas, G. Kofidis, A Bosabalidis, and A. Nastou. 2002. Water stress affects leaf anatomy, gas exchange, water relations and growth of two avocado cultivars. Scientia Hort. 95:39-50.

Chimonidou-Pavlidou, D. 2004. Malformation of roses due to drought stress. Scientia Hort. 99:79-87.

Fulcher, A., A.V. LeBude, J.S. Owen, S.A. White, and R.C. Beeson. 2016. The next ten years: Strategic vision of water resources for nursery producers. HortTechnology 26:121-132.

Gow, W-P., J-T. Chen, and W-C. Chang. 2010. Enhancement of direct somatic embryogenesis and plantlet growth from leaf explants of 
Phalaenopsis by adjusting culture period and explant length. Acta Physiol. Plant. 32:621-627.

Guerfel, M., O. Baccouri, D. Boujnah, W. Chaibi, and M. Zarrouk. 2009. Impacts of water stress on gas exchange, water relations, chlorophyll content and leaf structure in the two main Tunisian olive (Olea europaea L.) cultivars. Scientia Hort. 119:257-263.

Guo, W-J. and N. Lee. 2006. Effect of leaf and plant age, and day/night temperature on net $\mathrm{CO}_{2}$ uptake in Phalaenopsis amabilis var. formosa. J. Amer. Soc. Hort. Sci. 131:320-326.

Hwang, S.J. and B.R. Jeong. 2007. Growth of Phalaenopsis plants in five different potting media. J. Jpn. Soc. Hort. Sci. 76:319-326.

IPCC. 2007. Climate change 2007: Synthesis report. 1 Mar. 2011. <http://www.ipcc.ch/pdf/ assessment-report/ar4/syr/ar4_syr.pdf>.

Kim, H.J., J. Kim, D.L. Yun, K.S. Kim, and Y.J. Kim. 2016. Growth and flowering of Doritaenopsis Queen Beer 'Mantefon'as affected by different potting substrates. Hort. J. 85:360-365.

Kim, J., A. Malladi, and M.W. van Iersel. 2012. Physiological and molecular responses to drought in Petunia: The importance of stress severity. J. Expt. Bot. 63:6335-6345.

Kim, J., M.W. van Iersel, and S.E. Burnett. 2011. Estimating daily water use of two petunia cultivars based on plant and environmental factors. HortScience 46:1287-1293.

Kluge, M. and I.P. Ting. 2012. Crassulacean acid metabolism: Analysis of an ecological adaptation. Springer Science \& Business Media, Berlin, Germany.

Lea-Cox, J.D., G.F. Kantor, and A.G. Ristvey. 2008. Using wireless sensor technology to schedule irrigations and minimize water use in nursery and greenhouse production systems. Comb. Proc. Intl. Plant Prop. Soc. 58:1-7.

Lopez, R.G. and E.S. Runkle. 2005. Environmental physiology of growth and flowering of orchids. HortScience 40:1969-1973.

Meng, L., L-X. Li, W-F. Chen, Z. Xu, and L-X. Liu. 1999. Effect of water stress on stomatal density, length, width and net photosynthetic rate in rice leaves. J. Shenyang Agr. Univ. 30:477-480.

Mishra, G., W. Zhang, F. Deng, J. Zhao, and X. Wang. 2006. A bifurcating pathway directs abscisic acid effects on stomatal closure and opening in Arabidopsis. Science 312:264-266.

Nash, N. 2003. Phalaenopsis primer: A beginner's guide to growing moth orchids. Orchid Soc. Bul. 72:705-706.

Nemali, K.S. and M.W. van Iersel. 2006. An automated system for controlling drought stress and irrigation in potted plants. Scientia Hort. 110:292-297.

Niu, G., D.S. Rodriguez, L. Rodriguez, and W. Mackay. 2007. Effect of water stress on growth and flower yield of Big Bend bluebonnet. Hort Technology 17:557-560.

Nobel, P.S. 1977. Water relations and photosynthesis of a barrel cactus, Ferocactus acanthodes, in the Colorado desert. Oecol. 27:117-133.

O’Meara, L., M.R. Chappell, and M.W. van Iersel. 2014. Water use of Hydrangea macrophylla and Gardenia jasminoides in response to a gradually drying substrate. HortScience 49:493-498.

Ota, K., K. Morioka, and Y. Yamamoto. 1991. Effects of leaf age, inflorescence, temperature, light intensity and moisture conditions on CAM photosynthesis in Phalaenopsis. J. Jpn. Soc. Hort. Sci. 60:125-132.

Pershey, N.A., B.M. Cregg, J.A. Andresen, and R.T. Fernandez. 2015. Irrigating based on daily water use reduces nursery runoff volume and nutrient load without reducing growth of four conifers. HortScience 50:1553-1561.

Sauter, A., W.J. Davies, and W. Hartung. 2001. The long-distance abscisic acid signal in the droughted plant: The fate of the hormone on its way from root to shoot. J. Expt. Bot. 52:1991-1997.

USDA. 2016. Floriculture crops 2015 summary, U.S. Dept. Agr., Washington, DC.

Valdés, R., J. Ochoa, J. Franco, M. SánchezBlanco, and S. Bañón. 2015. Saline irrigation scheduling for potted geranium based on soil electrical conductivity and moisture sensors. Agr. Water Mgt. 149:123-130. van Iersel, M., R.M. Seymour, M. Chappell, F. Watson, and S. Dove. 2009. Soil moisture sensor-based irrigation reduces water use and nutrient leaching in a commercial nursery. Proc. Southern Nursery Assn. Res. Conf. 54:17-21.

Vereniging van Bloemenveilingen in Nederland. 2017. Annual report 2016. Association of Dutch Flower Auctions, Leiden, The Netherlands.

Wang, Y-T. 1995. Phalaenopsis orchid light requirement during the induction of spiking. HortScience 30:59-61.

Wang, Y-T. 1997. Phalaenopsis light requirements and scheduling of flowering. Orchids 66:934 939.

Wang, Y-T. 2000. Impact of a high phosphorus fertilizer and timing of termination of fertilization on flowering of a hybrid moth orchid. HortScience 35:60-62.

Wang, Y-T. 2007. Potassium nutrition affects Phalaenopsis growth and flowering. HortScience 42:1563-1567.

Wang, Y-T. 2010. Phalaenopsis mineral nutrition. Acta Hort. 878:321-333.

Wang, Y-T. and L.L. Gregg. 1994. Medium and fertilizer affect the performance of Phalaenopsis orchids during two flowering cycles. HortScience 29:269-271.

Wang, Y-T. and N. Lee. 1994. Potted blooming orchids. Greenhouse Grower 12(1):79-80.

Warsaw, A., R.T. Fernandez, B.M. Cregg, and J.A. Andresen. 2009. Container-grown ornamental plant growth and water runoff nutrient content and volume under four irrigation treatments. HortScience 44:1573-1580.

$\mathrm{Xu}, \mathrm{Z}$. and G. Zhou. 2008. Responses of leaf stomatal density to water status and its relationship with photosynthesis in a grass. J. Expt. Bot. 59:3317-3325.

Yen, W-Y., Y-C.A. Chang, and Y-T. Wang. 2011. The acidification of sphagnum moss substrate during Phalaenopsis cultivation. HortScience 46:1022-1026. 